\title{
Cassava root meal as an energy source for dairy cattle
}

\author{
J. M. Martins ${ }^{\dagger}$, A. F. Nunes, J. L. André and A. vaz Portugal \\ Estação Zootécnica Nacional, 2000 Santerém, Portugal
}

\section{Introduction}

Early lactation requires high energy inputs due to the levels of production obtained. Cassava, a high energy food, may fulfil these input requirements. The following experiments were designed to optimize the use of cassava as an ingredient of concentrate diets for dairy cows.

\section{Material and methods}

Two feeding trials carried out in a complete randomized-block design, involved 14 (experiment $1-\mathrm{E} 1$ ) and 16 (experiment 2-E2) black and white cows allocated to two treatments within each experiment, according to previous yields and number of lactations.
Control (barley concentrate) was the same for both experiments. Barley/cassava concentrate (E1) consisted of a mixture in which $500 \mathrm{~g} / \mathrm{kg}$ barley in the control diet was replaced by cassava root meal (CRM). In the cassava concentrate (E2) $782 \mathrm{~g} / \mathrm{kg}$ barley was replaced by CRM. Composition, dry matter and crude protein contents of the concentrates are shown in Table 1. CRM utilized in both experiments was analysed (Table 2 ).

All concentrates were isonitrogenous and during the trials, pasture (grazed white clover and fescue) and water were available ad libitum.

Experiments started after calving and lasted for $\mathbf{1 0}$ weeks. Cows were given $5 \mathrm{~kg}$ concentrate daily. Milk

Table 1 Composition and chemical analysis of concentrates

\begin{tabular}{lccc}
\hline \hline & $\begin{array}{c}\text { Barley concentrate } \\
\text { (experiments 1 and 2) }\end{array}$ & $\begin{array}{c}\text { Barley/cassava concentrate } \\
\text { (experiment 1) }\end{array}$ & $\begin{array}{c}\text { Cassava concentrate } \\
\text { (experiment 2) }\end{array}$ \\
\hline Composition (g/kg) & 780 & 365 & 170 \\
$\quad$ Barley & & 365 & 510 \\
$\quad$ Cassava & 180 & 230 & 280 \\
Soya-bean & 40 & 40 & 40 \\
Pre-mix & & & 875 \\
Chemical analysis $(\mathrm{g} / \mathrm{kg})$ & 840 & 150 & 858 \\
$\quad$ Dry matter & 150 & 850 \\
$\quad$ Crude protein & & & 150 \\
\hline \hline
\end{tabular}

Table 2 Chemical and biological composition of cassava root meal

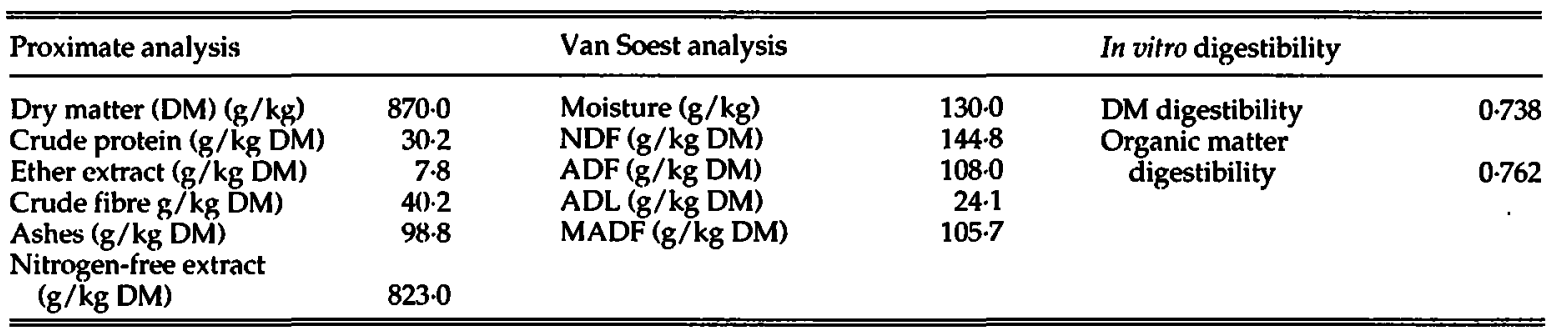

† Present address: Centro Veterinária e Zootecnia, Instituto Investigação Científica Tropical, Faculdade Medicina Veterinária, Rua Gomez, Freire, 1199 L.isboa Codex, Portugal. 
Table 3 Milk production and composition and mean live weight and live-weight loss during the experiments

\begin{tabular}{|c|c|c|c|c|c|}
\hline & $\begin{array}{l}\text { Milk yield } \\
\text { (kg/day) }\end{array}$ & $\begin{array}{l}\text { Milk fat } \\
(\mathrm{g} / \mathrm{kg})\end{array}$ & $\begin{array}{l}\text { Milk protein } \\
(\mathrm{g} / \mathrm{kg})\end{array}$ & $\begin{array}{l}\text { Milk live weight } \\
\text { (kg) }\end{array}$ & $\begin{array}{l}\text { Mean weight } \\
\text { loss }(\mathrm{kg})\end{array}$ \\
\hline \multicolumn{6}{|l|}{ Experiment 1} \\
\hline Treatment 1 (Barley concentrate) & $25 \cdot 3$ & 30.7 & 29.3 & $541 \cdot 0$ & $25 \cdot 0$ \\
\hline Treatment 2 (Barley/cassava concentrate) & $25 \cdot 6$ & $30 \cdot 4$ & $27 \cdot 8$ & $525 \cdot 0$ & $26 \cdot 0$ \\
\hline \multicolumn{6}{|l|}{ Experiment 2} \\
\hline Treatment 1 (Barley concentrate) & $25 \cdot 9$ & 32.8 & $30 \cdot 2$ & $550 \cdot 0$ & 39.0 \\
\hline Treatment 2 (Cassava concentrate) & $25 \cdot 3$ & 33.5 & 31.4 & 565.0 & $40 \cdot 0$ \\
\hline
\end{tabular}

production was recorded daily and individually. Milk samples were taken for compositional analysis every fortnight. Cows were weighed weekly.

All results were statistically treated by the analysis of variance method of Steel and Torrie (1960).

\section{Results}

There were no significant differences $(P>0.05)$ in mean daily milk yields, mean fat and protein contents, mean live weight and live-weight variation between treatments within experiments (Table 3 ).

\section{Discussion}

Mean daily milk yields of treatments for each experiment were not significantly different $(P>0.05)$. This finding is supported by several authors in experiments where barley was partially replaced by cassava (Brigstocke, Cuthbert, Thickett, Lindeman and Wilson, 1981; Kirilov, Buzik, Ilyukhina and Samokhin, 1984) and in others where cassava replaced totally or partially, other cereals (Kirilov, Naumenko and Kirilova, 1987; Ribeiro, Moreira, Vilela and Silva, 1976). The absence of difference between treatments in both experiments could be the result of a similar energy content of concentrates. On the other hand, the contribution of body reserves to milk production was similar between treatments within each experiment. Therefore, the absence of significant differences in milk yields may be the result of equal influences of treatments and body reserves in the two experiments. These facts were also reported by Olaloku, Egeuiwe and Oyenuga (1971), Ribeiro et al. (1976) and Brigstocke et al. (1981).
With respect to milk composition, there were no significant differences $(P>0.05)$ in mean fat and protein content, as also reported by Brigstocke ct al. (1981). The mean milk fat content, which was slightly low in both experiments, is common in early lactation where a dilution effect may be present.

Results obtained in these trials allow us to conclude that it is possible to replace barley by cassava (up to $780 \mathrm{~g} / \mathrm{kg}$ ) in concentrate rations for dairy cows, without encountering any deleterious effects on the productive response of the animals.

\section{References}

Brigstocke, T. D. A., Cuthbert, N. H., Thickett, W. S., Lindeman, M. A. and Wilson, P. N. 1981. A comparison of a dairy cow compound feed with and without cassava given with grass and silage. Animal Production 33: 19-24.

Kirilov, M. P., Buzik, R. B., llyukhina, L. A. and Samokhin, A. V. 1984. Tapioca in diets for lactating cows. Nutrition Abstracts and Ruvicus (Sirics B) 54: 603.

Kirilov, M. P., Naumenko, P. A. and Kirilova, N. I. 1987. Digestive processes in lactating cows and fattening pigs given diets with cassava. Nutrition Abstracts and Revicws (Series B) 57: 659.

Olaloku, E. A., Egeuiwe, A. M. and Oyenuga, V. A. 1971. The influence of cassava in the production ration, on the yield and composition of milk of White Fulani cattle. In Abstracts on Cassava (Manihot esculenta, Crantz), vol. II. Cassava Information Center, CIAT, 1976, Cali, Colombia.

Ribeiro, P. J., Moreira, H. A., Vilela, H. and Silva, T. 1976. Melaço desidratado e raspa de mandioca como substitutos parciais do milho para produção de leite. Arquious de Escola de Veterinaria, Uninersidade de Minas Gerais 28: 193-200.

Steel, R. G. D. and Torrie, J. H. 1960. Principles and procedures of statistics. McGraw-Hill, New York. 